\title{
Riposte to Editorial 6/3 January, 1999
}

The Editorial, 'Brands and ethics - oil and water?', by Richard Zambuni confirms the main thrust of my paper in the same January 1999 issue of The Journal of Brand Management 6/3, pp. 198-210, that 'ethics' are important for brands.

We disagree, however, on some substantive points. Firstly, I was taken aback by $\mathrm{Mr}$ Zambuni's suggestion that I recommend 'ethics laws/legislation' drawn up by governments, as a means of achieving corporate ethics and his thesis goes on to demolish my so-called proposal. Of course, Richard Zambuni is entitled to argue against 'ethics legislation' but not, please, to attribute the thesis to me! Rather, my paper puts forward, as an original proposal, 'Eight Ethical Performance Targets' as the means by which companies and brands might achieve enhanced reputation and ethical performance.

The Introduction (p. 199) does refer to 'ethics laws' enacted by some governments covering the behaviour of public servants: for example, the post-Watergate federal ethics statute in the United States. However, I was defining as a statement of fact what 'ethics' means in different countries, not making a recommendation. There is some confusion in Europe about the term 'ethics' and a lack of awareness that 'ethics laws' by that name have been enacted already by governments in some countries in respect of public office holders.

As part of the 'Eight Ethical Performance Targets' I suggest that existing legislation relating to the environment, health and safety, and criminal offences such as insider-dealings, be adhered to by brands as part of their responsible attitude and ethical stance, but I do not propose 'ethics legislation' of the kind Mr Zambuni criticises. Consequently, his Editorial title 'Brands and ethics - oil and water?' becomes inappropriate. 'Brands and ethics go together', I would suggest, 'like a horse and carriage' in a suitable marriage!

Secondly, Richard Zambuni puts forward his own views that the citizen and the market can result in ethical companies and products. Is this true? We have seen, for example, in Russia that corruption can fill the vacuum in the absence of a developed market economy. Even in a country like the United Kingdom, where a market economy exists, factors like overly-high executive salaries and share option schemes vis-à-vis wage levels in the rest of a company, have led to the setting up of a self-regulatory Committee on Corporate Governance to set principles and rules relating to directors' remuneration and guidance for corporate control. The UK Labour Government has stated that it may introduce legislation if this voluntary Code does not work (my paper p. 203). Again, this is a statement of fact, not my own proposal. To avoid such legislation UK companies and brand leaders must ensure that the self-regulatory Code on Corporate Governance is upheld. The market and the citizen alone are insufficient to govern these aspects of corporate behaviour.

I agree with Mr. Zambuni's focus on the importance of the role of consumers, citizens and the market. I do not recommend in my paper 'ethics legislation' but I do endorse the value of 'brands and ethics going together'. The 'Ethical Performance Targets' I pinpoint are intended to help and assist the CEO and others in a company to ensure that corporate ethics are not just debated (as Mr Zambuni proposes) but are embodied also in corporate policy and its implementation.

Dr Rosamund Thomas Director

Centre for Business and Public Sector Ethics, Cambridge (UK)

Tel: +441223 357458

Fax: + 441223303598 